\section{Pulmonary oedema after airway obstruction due to bilateral vocal cord paralysis}

Shuji Dohi MD, Naomitsu Okubo MD, Youichi Kondo MD

\begin{abstract}
We report a case of pulmonary oedema which developed after airway obstruction due to bilateral vocal cord paralysis. The patient was a 52-yr-old woman undergoing cramiotomy for an acoustic neuroma. Anaesthesia was unevenful. Spontaneous ventilation resumed after reversal of neuromuscular blockade. Following extubation she showed signs of airway obstruction and dyspnoea. The trachen was reinubated but she became hypoxic, $\mathrm{PaO}_{2}-36 \mathrm{mmHg}$, produced pink frothy secretions and the $x$-ray was typical of pulmonary oedema. The oedema cleared within $24 \mathrm{hr}$. Tracheostomy was performed one week later as the cords were still fixed, but the latter had recovered by three months and the tracheostomy was closed. The cause of the cord paralysis is unknown but probably was a result of surgical trauma to the brain stem.
\end{abstract}

On rapporte le cas d'un patient ayant développé un adème pulmonaire aiguë après obstruction des voies aériennes snite $a$ une paralysie bilatérale des cordes vocales. La patiente âgée de 52 ans a subi une craniotomie pour un neuroninone acoustique. L'anesthésie fut accomplie sans incident. La ventilation spontanée fut reprise après antagonisme du blocage neuromusculaire. Après l'exmbation, la patiente a démontré des signes d'obstruction des voies aériennes et de la dyspnée. La trachée fut réintubée mais la patiente devint hypoxique, $\mathrm{PaO}_{2}-36 \mathrm{mmHg}$, et on a observé des sécrétions spumeuses rosées et le rayon-x a démontré un adème pulmonaire typique. L'adème a régressé en dedans de 24 heures. Une trachéostomie fur faite une semaine

\section{Key words}

AIRWAY: obstruction;

LUNG: oedema.

From the Department of Anaesthesiology, Gifu University School of Medicine, Gifu City, Gifu, and the Department of Anaesthesiology, Institute of Clinical Medicine, University of Tsukuba, Tsukuba City, Ibaraki, Japan.

Address correspondence to: Dr. Shuji Dohi, Department of Anaesthesiology, Gifu University School of Medicine, Gifu City, Gifu 500 Japan.

Accepted for publication I8th January, 1991. plus tard car les cordes vocales étaient encore fermées et la récupération s'ensuivie trois mois plus tard, c'est alors que la trachéostomie fut fermée. La cause de la paralysie des cordes vocales n'est pas comme mais serait due probablement au trauma chirurgical.

Airway obstruction may cause pulmonary oedema in both awake and anaesthetized patients. ${ }^{1-16}$ Acute airway obstruction produces a large subatmospheric transpulmonary pressure gradient elicited by attempts to breathe against a closed glottis, or narrowed airway. 5,17-19 Reported cases included hanging or strangulation, 1,14 laryngospasm during induction of or emergence from anaesthesia, ${ }^{2-4,8,10,12,15,16}$ laryngeal obstruction by tumour, tracheal obstruction due to goitre or neoplasm, 1,14 croup, acute infectious pharyngitis or epiglottitis, ${ }^{6,13}$ and laryngeal haematoma. " Vocal cord paralysis also causes airway obstruction, but complete obstruction is rare in adults. ${ }^{20-24}$ In a recent review, there were no reports of pulmonary oedema occurring after vocal cord paralysis. ${ }^{25}$ We report a case in which pulomonary oedema occurred after airway obstruction due to bilateral vocal cord paralysis in a patient undergoing cerebellopontine angle surgery.

\section{Case report}

A 52-yr-old female (weight of $45 \mathrm{~kg}$ ) with regrowth of a right acoustic neuroma was scheduled for craniotomy and removal of the tumour. Her past medical and three surgical records revealed right facial palsy, nystagmus indicating the involvement of fifth, seventh and eighth cranial nerves but no previous anaesthetic complication. The patient also showed left-sided cerebellar gait disturbance and some signs of intracranial hypertension. The patient received diazepam, $10 \mathrm{mg}$, po, $90 \mathrm{~min}$ before arrival in the operating room. After an iv catheter, ECG and direct arterial blood pressure monitoring were provided, anaesthesia was induced with thiamylal, $5 \mathrm{mg} \cdot \mathrm{kg}^{-1}$ iv, and manual hyperventilation of the lungs was performed using enflurane, nitrous oxide and oxygen. Pancuronium $6 \mathrm{mg}$ iv was given to facilitate tracheal 
intubation together with lidocaine $70 \mathrm{mg}$ to depress the associated cardiovascular responses. A tracheal tube (7.5 $\mathbf{m m}$, profile cuff tube, Portex) was placed in the patient's trachea and the cuff was inflated with air. The vocal cords were difficult to visualize but intubation was performed "blindly" by direct laryngoscopy. The anaesthetic course was uneventful for the seven-hour operation during which the patient's condition was stable (systolic BP remained between 100 and $140 \mathrm{mmHg}$, heart rate $78-90 \mathrm{bpm}, \mathrm{CVP}$ 3-4 $\mathrm{cmH}_{2} \mathrm{O}$, body temperature $34.9-36.3^{\circ} \mathrm{C}, \mathrm{PaO}_{2}$ $160-178 \mathrm{mmHg}, \mathrm{PaCO}_{2} 31-34 \mathrm{mmHg}$ with $33 \%$ oxygen, $67 \%$ nitrous oxide and $0.6-1.5 \%$ enflurane). She received a total of $800 \mathrm{ml}$ whole blood and $1500 \mathrm{ml}$ of lactated Ringer's solution, and the blood loss and urine output during anaesthesia were $978 \mathrm{ml}$ and $380 \mathrm{ml}$, respectively.

After residual neuromuscular blockade with pancuronium was reversed by neostigmine, $2.5 \mathrm{mg}$, and atropine, $1.0 \mathrm{mg}$, the patient regained consciousness and responded to commands regarding grasp and movement of the extremities. During the emergence from anaesthesia her systolic BP increased from $110-120 \mathrm{mmHg}$ to $146-176$ $\mathrm{mmHg}$ and the tracheal lube was removed without difficulty. Immediately after extubation, paradoxical chest motion was noted, and the patient became progressively dyspnoeic. Manual ventilation with $100 \%$ oxygen by a mask did not improve her condition. Two to three minutes after extubation arterial blood gas analysis showed $\mathrm{PaO}_{2} 309 \mathrm{mmHg}, \mathrm{PaCO}_{2} 68 \mathrm{mmHg}$, and $\mathrm{pHa}$ 7.265. Laryngospasm was suspected, but the patient was alert and was able to attempt several deep breaths with marked suprasternal and subcostal retractions on command. A few minutes later the trachea was reintubated. There was no gag reflex and no reaction to laryngoscopy and tracheal intubation. Five minutes later blood gas analysis showed $\mathrm{PaO}_{2} 36 \mathrm{mmHg}, \mathrm{PaCO}_{2} 64 \mathrm{mmHg}$ while the patient breathed spontaneously on room air. Immediate suction produced a mass of pink frothy secretions through the tracheal tube. A portable CXR showed a normal heart size but diffuse and fluffy bilateral alveolar infiltration which was prominent in right upper lobe regions, and obliteration of the hilar shadows. A sample of the pulmonary oedema fluid, a total of $132 \mathrm{ml}$ collected for about $30 \mathrm{~min}$, showed a total protein content of 6.3 $\mathrm{mg} \cdot \mathrm{dl}^{-1}$ and a pulmonary oedema fluid-serum protein ratio of 0.92 (Table).

During positive-pressure ventilation of the lungs with end-expiratory pressure (PEEP) and intermittent manual hyperinflation, $\mathrm{PaO}_{2}$ gradually improved over next six hours and the amount of suctioned pulmonary oedema fluid progressively decreased. Approximately $18 \mathrm{hr}$ after the onset of pulmonary oedema, $\mathrm{PaO}_{2}$ was $154 \mathrm{mmHg}$ and $\mathrm{PaCO}_{2}$ was $39 \mathrm{mmHg}$ with a tidal volume of $350 \mathrm{ml}$
TABLE Components of pulmonary oedema fluid and serum, $15 \mathrm{~min}$ after the onset of pulmonary oedema

\begin{tabular}{|c|c|c|c|c|}
\hline Component & $P E$ fluid & Serum* & $\begin{array}{l}\text { (Normal ran } \\
\text { in serwm }\end{array}$ & gge) \\
\hline Total protein & 6.3 & 6.7 & $6.5 \sim 8.2$ & $d \cdot d I^{-1}$ \\
\hline Albumin & 3.6 & 3.7 & $3.1 \sim 5.1$ & $\mathrm{~g} \cdot \mathrm{dl}^{-1}$ \\
\hline$A / G$ & 1.33 & 1.23 & $1.4 \sim 2.2$ & \\
\hline Calcium & 9.9 & 9.0 & $8.2 \sim 10.8$ & $\mathrm{mg} \cdot \mathrm{dl}^{-1}$ \\
\hline Inorganic phosphate & 4.8 & 4.3 & $2.5 \sim 5.5$ & $\mathrm{mg} \cdot \mathrm{dl}^{-1}$ \\
\hline Sodium & 161 & 141 & $134-147$ & $\mathrm{mEq} \cdot \mathrm{L}^{-1}$ \\
\hline Chloride & 130 & 109 & $96-110$ & $\mathrm{nIEq} \cdot \mathrm{L}^{-1}$ \\
\hline Potassium & 9.1 & 3.1 & $3.7 \sim 5.0$ & $\mathrm{mEq} \cdot \mathrm{L}^{-1}$ \\
\hline Urea nitrogen & 15.9 & 12.0 & $8.0 \pm 20.0$ & $\mathrm{mg} \cdot \mathrm{dl}^{-1}$ \\
\hline Creatinine & 0.7 & 0.7 & $0.4 \sim 1.1$ & $\mathrm{mg} \cdot \mathrm{dl}^{-1}$ \\
\hline Uric acid & 1.3 & 3.9 & $2.0 \sim 6.0$ & $\mathrm{mg} \cdot \mathrm{dl}^{-1}$ \\
\hline CPK & 211 & 105 & $0 \sim 165$ & $I U \cdot L^{-1}$ \\
\hline CPK-MB & 255 & 18 & $5 \sim 30$ & $I U \cdot L^{-1}$ \\
\hline SGOT & 64 & 22 & $0 \sim 40$ & $I U \cdot L^{-1}$ \\
\hline SGPT & 0 & 6 & $0 \sim 40$ & $I U \cdot L^{-1}$ \\
\hline LDH & 2699 & 390 & $120 \sim 520$ & $\mathrm{IU} \cdot \mathrm{L}^{-1}$ \\
\hline Alkaline phosphatase & 353 & 87 & $50 \sim 230$ & $I U \cdot L^{-1}$ \\
\hline Choline esterase & 45 & 277 & $170 \sim 420$ & $I U \cdot L^{-1}$ \\
\hline Amylase & 590 & 105 & $40 \sim 240$ & $I U \cdot L^{-1}$ \\
\hline Bilirubin & 1.1 & 1.3 & $0.2 \sim 1.0$ & $\mathrm{mg} \cdot \mathrm{dl}^{-1}$ \\
\hline \multirow[t]{2}{*}{ Osmolarily } & 340 & 296 & $275 \sim 295$ & $\mathrm{mOsm} \cdot \mathrm{L}^{-1}$ \\
\hline & PE fluid & Blood* & & \\
\hline WBC $\left(\times 10^{3}\right)$ & 2.1 & 12.8 & & \\
\hline $\operatorname{RBC}\left(\times 10^{6}\right)$ & 0.19 & 4.54 & & \\
\hline $\mathrm{Hb}\left(\mathrm{g} \cdot \mathrm{dl}^{-1}\right)$ & 1.1 & 14.5 & & \\
\hline $\mathrm{Ht}(\%)$ & 1.7 & 42.4 & & \\
\hline Platelet $\left(\times 10^{3}\right)$ & 5.7 & 139 & & \\
\hline Haemolysis & 58 & 0 & & \\
\hline
\end{tabular}

*Results of simultaneous arterial blood sample.

and $30 \%$ inspired oxygen using CPAP of $5 \mathrm{cmH}_{2} \mathrm{O}$. Repeated CXR showed that the pulmonary infiltrates had resolved. Since she was alert and her genearal condition was very stable, her trachea was extubated, but she complained of difficulty in breathing; she breathed with a very husky voice and inspiratory dyspnoea was noted. Soon after she became cyanosed and the trachea was reintubated. Examination of the laryn $x$ and vocal cords with a fibreoptic bronchoscope found no laryngeal oedema, but revealed that both true cords were fixed in the midline with a 1-2 mm airway. Bilateral vocal cord paralysis due to recurrent laryngeal nerve palsy was suspected.

Neurological examinations revealed anisocoria (right$>$ left), bilateral horizontal nystagmus, bilateral VIl nerve paresis, left VI palsy, depressed gag reflex, ataxia, and aphonia. A CT examination revealed left-sided shift of the brain stem due to the CP angle mass and low density area around the rostral medulia oblongata and caudal pons, and some clots in the fourth ventricle.

One week later, laryngoscopy revealed bilateral vocal 
cord fixed and 14 th postoperative day, the extubation was unsuccessful. Tracheostomy was performed under local anaesthesia.

The course of rehabilitation was uneventful. Three months later, the tracheostomy cannula was removed because the movement of vocal cords recovered. The patient discharged although the neurological deficits remained.

\section{Discussion}

Laryngospasm and laryngeal oedema are the most serious immediate airway problems following extubation of the trachea. In the present case, we postulated that the airway obstruction after extubation of tracheal tube was initially due to laryngospasm and then due to laryngeal oedema. ${ }^{24.26}$ Laryngospasm is unlikely if the depth of anaesthesia is sufficient during extubation of the trachea or the patient is allowed to awaken before the extubation. Laryngeal oedema, though rare, occurs especially in children ${ }^{24}$ or after neck surgery. Difficulty in the visualization of the larynx and vocal cords prevent them from being differentiated.

Bilateral vocal cord paralysis following tracheal intubation $^{20-23}$ or without previous intubation ${ }^{27,28}$ is a rare cause of airway obstruction. After four attempts at extubation resulted in acute airway obstruction we suspected recurrent laryngeal nerve palsy. Although rare, it has been recognized after tracheal intubation but usually does not cause airway obstruction. ${ }^{20-23}$ It may have occurred in this patient following compression of the peripheral anterior branches of recurrent nerve ${ }^{21.23}$ by an over-inflated cuff or following vocal cord trauma due to "blind" intubation.

There are reports of bilateral vocal cord paralysis leading to acute airway obstruction occurring in patients with brain stem ischaemia ${ }^{27}$ and stroke. ${ }^{28}$ In this patient postoperative neurological and brain CT examinations suggested local ischaemia of lower cranial neuronal regions. It is possible that the surgical intervention of the brain stem region may have caused the paralysis. The nucleus ambiguus occupies much of the rostral medulla and caudal pons and the axons of the motor neurones innervating the pharynx, larynx and upper oesophagus pass via the $9 \mathrm{th}$, 10th, and $1 /$ th cranial nerves. The neurons serving abduction are phylogenetically newer and fewer than the adductor neurons, ${ }^{28}$ and are more susceptible to injury. ${ }^{28}$ Also, since the adductors have three times more muscle mass than the abductors, injury to the abductor neurons can be responsible for cord spasm in adduction. The anterior branch of the recurrent laryngeal nerve innervates the cord adductors and is vulnerable to compression between an expanded cuff and the overlying thyroid cartilage. Thus, cord paralysis due to tracheal tube cuff compression usually leaves them in the intermediate position and thus hoarseness, but not airway obstruction, is more likely. ${ }^{21}$ Therefore the bilateral vocal cord paralysis in this patient was more likely to have been due to insult of the brain stem than to local recurrent laryngeal nerve palsy.

The development of pulmonary oedema as a complication of upper airway obstruction is rare but wellrecognized. Mechanisms for its development are not well understood but it is suggested that increased permeability is the principal cause. The large negative intrathoracic pressure favours transudation of fluid from the pulmonary capillaries into the alveolar space. $4,5,10,14,16,18$ It is possible that pulmonary oedma occurred from neurogenic mechanisms associated with the surgery as has been reported in traumatic cerebral impact, cerebral compression, and seizures. ${ }^{29-31}$ This is unlikely because there was no evidence of sympathetic overactivity, or increased intracranial pressure.

The high protein content of the oedema fluid (pulmonary oedena fluid/serum ratio of 0.92 ) of the present patient suggests that the pulmonary oedema followed increased permeability. ${ }^{32.33}$ Experimentally, high oede$\mathrm{ma}$ fluid/serum protein ratio has been reported in permeability oedema $(0.98 \pm 0.05)$, whereas lower values have been reported in neurogenic oedema $(0.48 \sim 0.84)$ and in haemodynamic oedema $(0.54 \pm 0.04)$ in dogs. ${ }^{32}$

We have not previously experienced bilateral vocal cord paralysis as a complication of cerebellopontine surgery. Surgical procedures in this region may be associated with a variety of potential, rare complications. ${ }^{34}$ Indeed, a recent report described respiratory obstruction which occurred due to bilateral abductor vocal cord paralysis in infants with increased intracranial pressure with the Arnold-Chiari malformation. ${ }^{35}$ Postanaesthetic laryngospasm due to upper airway obstruction is the most frequent cause of the pulmonary oedema, ${ }^{16}$ but bilateral vocal cord paralysis should be considered as a potential cause of acute airway obstruction leading to pulmonary oedema.

\section{References}

I Oswall CE, Gates GA, Holmstrom FMG. Pulmonary edema as a complication of acute airway obstruction. JAMA 1977; 238: 1833-5.

2 Cozanitis DA, Leijala M, Pesonen E, Zaki HA. Acute pulmonary oedema due to laryngeal spasm. Anaesthesia 1982; 37: 1198-9.

3 Terry Lee KW, Downes JJ. Pulmonary edema secondary to laryngospasm in children. Anesthesiology 1983; 59: 347-9. 
4 Weissman C, Damask MC, Yang J. Noncardiac pulmonary edema following laryngeal obstruction. Anesthesiology 1984; 60: 163-5.

5 Galvis $A G$, Stool SE, Bluestone $C D$. Pulmonary edema following relief of acule upper airway obstruction. Ann Otol Rhino Laryngol 1980; 89: 124-8.

6 Travis $K W$. Todres $I D$, Shamon $D C$. Pulmonary edema associated with croup and epiglottitis. Pediatrics 1977; 59: 695-8.

7 Oswalt CF, Gates GA, Holmstromm FM. Pulmonary edema as a complication of acute airway obstruction. Review of Surgery 1977; 34: 346-7.

8 Jackson FN, Rowland V, Corssen G. Laryngospasm induced pulmonary edema. Chest 1980; 78: 819-21.

9 Melnick BM. Postlaryngospasm pulmonary edema in adults. Anesthesiology 1984; 60: 516-7.

10 Frank LP, Schreiber GC. Pulmonary edema following upper airway obstruction. Anesthesiology 1986; 65: 106.

II Bachmann P, Gaaurrprgues P, Pignat JC et al. Pulmonary edema secondary to warfarin-induced sublingual and laryngeal hematoma. Crit Care Med 1987; 15: 1074-5.

12 Jenkins JG. Pulmonary edema following laryngospasm. Anesthesiology 1984; 60: 611-2.

13 Solimann MG, Richer $P$. Epiglottitis and pulmonary edema in children. Can Anaesth Soc J 1987; 25: 270-5.

14 Kanter KR, Watchko JF. Pulmonary edema associated with upper airway obstruction. Am J Dis Child 1984; 138 : 356-8.

15 Andersen $B$, Kancir $C B$, Nielsen $K D$. Laryngospasminduced pulmonary edema. Acta Anaesthesiol Scand 1988; 32: 710-1.

16 Willms $D$, Shore $D$. Pulmonary edema due to upper airway obstruction in adults. Chest 1988; 94: 1090-2.

17 Sprung CL, Rackow EC, Fein A, Jacob Al, Isikoff SK. The spectrum of pulmonary edema: differentiation of cardiogenic, intermediate, and noncardiogenic forms of pulmonary edema. Am Rev Respir Dis 1981; 124: 718-22.

18 Stalcup SA, Mellins RB. Mechanical forces of producing pulmonary edema in acute asthma. N Engl J Med 1977; 297: 592-6.

19 Smith-Erichsen N, Bo G. Airway closure and fluid filtration in the lung. Br J Anaesth 1987; 51: 475-9.

20 Holly HS, Gildea JE. Vocal cord paralysis after tracheal intubation. JAMA 1971; 215: 281-4.

21 Cavo JW Jr. True vocal cord paralysis following intubation. Laryngoscope 1985; 95: 1352-9.

22 Brandwein M, Abramson AL, Shikowiz MJ. Bilateral vocal cord paralysis following endotracheal intubation. Arch Otolaryngol Head Neck Surg 1986; 112: 877-82.
23 Lim EK, Chia $K S, N g B K$. Recurrent laryngeal nerve palsy following endotracheal intubation. Anaesth Intensive Care 1987; 15: 342-5.

24 Jordan WS, Graves CL, Elwyn RA. New therapy for postintubation laryngeal edema and trachitis in children. JAMA 1970: 212: 585-8.

25 Lang SA, Duncan PG, Shephard DAE, Ha HC. Pulmonary oedema associated with airway obstruction. Can J Anaesth 1990; 37: 210-8.

26 Brand $J B$, Emerson $C W$, Wilson RS. Acute laryngeal edema 24 hours after passage of a nasogastric tube. Anesthesiology 1976; 45: 555-7.

27 Pender DJ. Laryngismus fugax: Transient laryngcal spasm secondary to brain stem ischemia. Laryngoscope 1984; 94: 1497-500.

28 Shaw GL. Airway obstruction due to bilateral vocal cord paralysis as a complication of stroke. South Med J 1987; 80: 1432-3.

29 Wray NP, Nicotra MB. Pathogenesis of neurogenic pulmonary edema. Am Rev Respir Dis 1978; 118: 783-6.

30 Malik $A B$. Mechanisms of neurogenic pulmonary edema. Circulation Res 1985; 57: 1-18.

31 Kreisman NR, Hodin RA, Rosemthal M, Sick TJ. Role of pulmonary edema in phasic changes of cerebral oxygenation during seizures. Brain Res 1987; 417: 335-42.

32 Maron $M B$. Analysis of airway fluid protein concentration in neurogenic pulmonary edema. J Appl Physiol 1987; 62: 470-6.

33 Sprung CL, Long WM, Marcial EH et al. Distribution of proteins in pulmonary edema. The value of fractional concentrations. Am Rev Respir Dis 1987; 136: 957-63.

34 Artru AA, Cucchiara RF, Messick JM. Cardiorespiratory and cranial-nerve sequelae of surgical procedures involving the posterior-fossa. Anesthesiology 1980; 52: 83-6.

35 Holinger $P C$, Holinger LD, Reichert TJ, Holinger $P H$ Respiratory obstruction and apnea in infants with bilateral abductor vocal paralysis, meningomyelocele, hydrocephalus, and Arnold-Chiari malformation. J Pediatr 1978; 92: 368-73. 